\title{
WHY NOT ENFORCE? A CRITICAL ANALYSIS OF THE REFUSAL TO ENFORCE FOREIGN JOINT CUSTODY JUDGMENTS IN TURKISH COURTS
}

\author{
ASLI BAYATA CANYAŞ*
}

*PhD, Ihsan Dogramaci Bilkent University Faculty of Law, Department of Private International Law, Ankara Turkey (bayata@bilkent.edu.tr).

\section{ABSTRACT}

The purpose of this article is to encourage the Turkish courts to eliminate their presumption against the enforcement of joint custody judgments, a presumption which is based on public policy grounds, so that these judgments are enforced in appropriate circumstances. As the number of marriages between Turkish and foreign nationals increases, more international family law conflicts will come into the picture. The termination of marriages by divorce brings with it many problems, among which custody of the children has great importance. Joint custody decisions are an important type of custody decisions, and the Turkish courts' approach to such decisions needs to be analysed from an international perspective. It is recommended that the Turkish Courts change their tendency to argue that custody is a subject which is directly connected to public policy and that foreign joint custody judgments cannot be enforced in Turkey since, under Turkish Civil Law, joint custody is not accepted. Our main conclusion is that, in cases where the parents are able to communicate effectively and to collaborate in a civilized manner for the sake of their child, and considering that such co-operation is in the interests of the child, public policy intervention should not occur, and the foreign joint custody judgment should be enforced.

\section{N T R O D U G T I O N}

One substantial issue remains for a judge who has granted a divorce decree to a couple who have children: how to deal with the custody of the children. When considering custody, which may affect the child's entire life, the judge should not only assess the subject from the legal and technical perspectives, but also make psychological and sociological assessments. The child's development in terms of mental health and as an independent individual explains why the psychological dimension is important, whereas his/her relationship with the family, which is a basic element of society, is the basis for the sociological 
aspect. Therefore, approaching the custody issue from a unified point of view, with the psychological and sociological aspects in tandem, may lead to a more desirable and fair outcome that fits with the circumstances of the individual case. The superior and privileged interests of the child should be placed at the centre of such an approach. Custody decisions should be made in a way that treats the child's sociological and psychological development as being of the utmost importance.

Within this framework, various custody conditions, including joint custody, sole custody, joint legal custody, joint physical custody, visiting rights accompanying sole custody, and even the prohibition of one parent from having any kind of personal relationship with the child for an unlimited period of time, may be granted. Sole custody gives one parent the right to make the decisions when bringing the child up, and is accompanied by a decision that the child will stay at that parent's home. The other parent is often entitled to see the child at certain times. In these circumstances, only one parent has the authority to make decisions concerning the child's life, on such subjects as the child's academic and religious education and moral and intellectual development.

The concept of joint custody began to emerge in the 1970s (Melli and Brown, 2008), but it does not have a clear definition and is generally assessed within the scope of the distinction between joint legal custody and joint physical custody (Barnes, 1999). The 'joint custody' movement which started in the early 1980s in the USA originally referred to joint legal custody i.e. the shared right to make decisions on subjects such as the child's religious upbringing, education, and medical issues; however, over time it came to be understood as 'joint physical custody'. In this context, both parents are required to spend a significant amount of time with the child (Parkinson, 2011). It might be said that joint legal custody emphasizes the autonomy and responsibility of both parents for making crucial decisions about bringing up the child. Even though the child stays at the home of one of the parents, or divides his/her time between the parents, both parents share equally in the responsibilities and rights with regard to the child's life. Joint physical custody, on the other hand, includes division of time between the parents, so that both the parents spend time with the child. This also requires taking responsibility for fulfilling the child's daily needs (Hardcastle, 1998-1999). Although the details may vary, joint physical custody includes spending around one-quarter to one-third of ordinary time with the child. It is sometimes computed on the basis of certain numbers of nights (for example, one hundred nights) per year (Buchanan and Jahromi, 2008), or the time may be shared between the parents according to the parents' schedules and the child's interests (Barnes, 1999). Today, there is a shift towards a different language, with phrases such as parenting plans, parental responsibility, and alternating residence. 
These terms are used to avoid the assumptions inherent in the language of custody. In Europe, for instance, the term 'custody' seems to have disappeared and to have been replaced by different terms like 'parental responsibility'. So it can be said that a strict model for establishing a presumption in favour of shared custody (in the sense of joint legal responsibility) does not exist in Europe (Parkinson, 2011).

In this article, the term 'joint custody' is preferred, since different parental arrangements are not yet familiar in Turkish law. Joint custody will be used to mean the shared responsibilities and powers of both parents when bringing up the child, together with a right to spend a meaningful amount of time with the child. In writing this article, reported and published decisions of the Turkish Supreme Court with regard to the enforcement of foreign joint custody judgments have been evaluated in order to reveal the Court's approach on the subject. The specific and concrete judgments have been generalized in an inductive manner, and it has been concluded that the Supreme Court rejects the enforcement of foreign joint custody judgments automatically, without questioning whether the judgment is for the benefit of the child and the family. The dissenting opinions in the judgments have also been classified and analysed, and the main rationale for these opinions has been categorized.

Since the subject has not only a legal aspect but also a psychological aspect, the results of psychological studies concerning the advantages and disadvantages of sole and joint custody have also been analysed. As a result of this analysis, it has become possible to reveal the circumstances under which joint custody is in the best interests of the child. After determining these circumstances, the approach of the Supreme Court in rejecting foreign joint custody judgments, which is based on public policy, has been evaluated under a critical lens.

\section{CUSTODY IN TURKISH DOMESTIC LAW}

In Turkish law, custody is perceived to be a subject that concerns the parents' rights and responsibilities regarding the child. In addition to granting the parents basic rights and responsibilities relating to the upbringing, education, and protection of the child, custody brings with it other duties like the management of the child's property or the naming of the child. In Turkish law, custody is a right which can only be entrusted to the parent(s). Under Article 348/2 of the Turkish Civil Code (CC), if it is not possible to give custody to either or both of the parents, a guardian is appointed by the court.

Under the Turkish CC, custody is regulated by virtue of three fundamental pillars. First, it is granted jointly to the parents if they are 
married (CC Article 335). Secondly, if the child is born to unmarried parents, custody is entrusted to the mother (CCArticle 337/1). Lastly, if the marriage terminates by divorce, custody is granted either to the mother or to the father (CC Article 336). Because of its importance, the last provision will be analysed separately below. Article 182 of the CC states that the "health, education and morality of the child have privileged roles while arranging the personal relations between the child and the non-custodian parent'. It has also been provided that the noncustodian parent is obliged to contribute to the child's day-care and education expenses at a rate proportional to that parent's income. When arranging the personal relationships in practice, certain criteria, like being in harmony with the social and economic conditions of the parents or satisfying the feelings of parenthood, are used (Huysal, 2005). In some exceptional cases, it is decided that the child and the non-custodian parent should not have any relationship at all. ${ }^{1}$ When a custody decision is made in the Turkish courts, since Turkey has ratified the United Nations Convention on the Rights of the Child, ${ }^{2}$ if the child is capable of understanding the circumstances of the case, he/she might be asked with which parent he/she would like to live. ${ }^{3}$ One may conclude that 'the interests of the child' play a key role in custody judgments in the Turkish courts. ${ }^{4}$ When analysing the child's interests, the child's physical, moral, intellectual, and psychological needs are considered. Not only the child's current interests, but also his/her future interests, are taken into consideration.

When the subject is approached from a conflict of laws point of view, it is observed that custody is subject to several international treaties; for issues that are outside the scope of those treaties, the Turkish Code on Private International and Procedural Law (CPIPL) applies. Therefore, if the subject is within the scope of a treaty, in principle the treaty prevails. This result is a requirement of Article $1 / 2$ of the CPIPL, which stipulates that international treaties which Turkey has ratified should primarily be applied. Under Turkish law, there are four main international treaties which are relevant for custody issues. These are the European Convention on Recognition and Enforcement Regarding Custody of Children ${ }^{5}$ ('the European Convention'), the Convention of 1961 Concerning the Powers of Authorities and the Law Applicable in Respect of the Protection of Minors, ${ }^{6}$ the Hague Convention of 25 October 1980 on the Civil Aspects of International Child Abduction, ${ }^{7}$ and, lastly, the Convention on Contact Concerning Children, which was approved by the Council of Ministers on 1 October 2011. ${ }^{8}$ This Convention aims to construct a system for both personal contact and the recognition and enforcement of custody judgments (Article 14/1/a). For states that require reciprocity for the recognition and enforcement of foreign judgments, the existence of this Convention might be accepted as a basis for reciprocity (Article 14/2). 
Article 336/2 of the Turkish CC, which regulates post-divorce custodial arrangements, states that 'the judge can entrust the custody to one of the spouses if the joint life is terminated or the separation occurs'. The provision is interpreted in a very strict way by the Turkish courts, and is deemed to be a provision which is directly linked to public policy in both domestic and international cases. As a result of this approach, custody both in the legal and the physical dimensions is entrusted only to one of the parents, meaning that sole custody is the only possibility after marriage breakdown or separation. The custodian parent resides with the child and makes all the important decisions, on matters such as education, religion, medical treatment, and management of the child's property, on his/her own. On the other hand, the non-custodian parent is only able to have a personal contact with the child for limited periods, such as weekends or specific holidays.

This strict sole custody approach of the Turkish courts with regard to post-divorce parenthood is different from the understanding in many other jurisdictions. There are indications in many Western countries of a very significant growth in different alternatives for parental arrangements after divorce or separation, such as alternating residence, parental agreements, or parental responsibility. The main rationale for these alternative parenthood models is the participation of both parents in the life of their child and the sharing of parental duties, responsibilities, and powers. All these alternatives have emerged as a result of a shift in the structure and the understanding of society, pressure from specific groups on the legislature, and the assessment of empirical studies.

In Europe, for instance, there is a tendency to arrange post-divorce parental roles so that the two parents share responsibilities and rights. To be more specific, Sweden allows courts to order 'alternating residence', according to which both parents may have the child residing with them. The decision is generally made as a result of the parents' agreement and by considering the child's best interests, and courts should only impose this against the wishes of a parent with care. For the model to succeed, the parents should act in a harmonized and cooperative manner, reside close to one another, and be flexible to the demands of their children. It is estimated that about 40 per cent of all children separated from their parents live in this way. The model is sometimes subject to criticism on the grounds that the parents might be forced into alternating residence against their will and that such a situation might aggravate the conflict between the parents and might not, therefore, be in the best interests of the child (Singer, 2008).

Similar developments in connection with post-divorce parental arrangements have occurred in Spain. Under the national law of $15 / 2005$, both the mother and the father are responsible for duties 
with regard to the child's life, and the child sometimes resides with the father and sometimes with the mother. An agreement made by the parents should be approved by the Public Prosecutor in order to ensure that the interests of the child are protected (Piconto Novales, 2012). The idea of continuing parental responsibility has also triggered reforms in Germany and France. In Germany, a 1997 law amended the $\mathrm{CC}$ and provided that parents have joint parental responsibility after marriage (Parkinson, 2011). In France, the CC was amended in 1993 and the term 'custody' was replaced by the term 'parental authority' (coparentalité), indicating that parental responsibility is to be exercised in common after divorce or separation (Parkinson, 2011). In England and Wales, the situation is similar to that in France, with terms like 'custody, guardianship, access' being abolished and replaced by 'parental responsibility', which implies that each parent has responsibilities and powers after the divorce or separation and emphasizes the indissoluble nature of being a parent (Parkinson, 2011).

Alternatives with regard to the post-divorce parental relationship have also emerged in other parts of the world. In many states of the USA, for instance, the parents are entitled to draw up a plan which may include their custodial responsibilities, a schedule showing how the child's time is to be split between them during weekends or holidays and a dispute resolution provision. The plan is subject to many linguistic formulations such as parenting plan or joint parenting agreement (Melli and Brown, 2008; Parkinson, 2011). In some states, such as Washington State, court intervention has been made possible in cases where the parents cannot reach an agreement (Parkinson, 2011). The shared involvement of the parents in the child's life after divorce has also been embraced in Australia (Parkinson, 2011). Upgrading a shared parenting regime by arranging equal time with each parent, or having a co-parenting model which enables different patterns for different families (for example, families where there is conflict or violence), have been discussed (Rhoades and Boyd, 2004). There have also been significant legislative reforms to encourage shared parenting through the Family Law Amendment (Shared Parental Responsibility) Act 2006. One of the objectives of the Act is to ensure that children benefit from the meaningful involvement of both parents in their lives after the breakdown of the marriage (Parkinson, 2011; for further developments in Australia, see Fehlberg et al, 2011). Under the reform process in Canada, a 'no one size fits all families' approach is being discussed, and people are seeking to replace the terms 'custody or access' by the term 'parenting time' (Parkinson, 2011). The aim is to abstain from any particular post-divorce parental arrangement and the focus is on the idea that every family has its own characteristics and that a parental arrangement should be designed which considers 
the internal dynamics of each family and the best interests of the child (Rhoades and Boyd, 2004).

It can be concluded that in many jurisdictions there is an 'evolution' towards sharing the parental duties and responsibilities after a divorce or separation. The demand by fathers to spend more time with their children and to participate in important decisions with regard to their children's lives has been an important triggering factor in this evolution. Fathers often complained that their connections with their children disappeared as a result of the active participation of mothers in sole custody. In Sweden (Singer, 2008), in Wisconsin (Melli and Brown, 2008), and in Australia and Canada (Rhoades and Boyd, 2004), for example, pressure exerted by fathers has played an important role in developing alternatives for post-divorce parenthood.

It may be that Turkish law, because of its strict perspective with regard to sole custody after marriage breakdown or separation, is at the very early stages of the evolution, and a search for post-divorce parenthood alternatives might flourish in time. Hence, fathers have started such a public pressure movement for joint rights and responsibilities after divorce. ${ }^{9}$ This movement, the climate of post-divorce parenting in other jurisdictions and its influence on Turkish law (such as through demands for the enforcement of joint custody judgments), and empirical studies on the subject might trigger the evolution. In this way, alternative models for sharing parental responsibilities by considering the best interests of the children might also be developed in Turkish family law.

RECOGNITION AND ENFORGEMENT OF FOREIGN CUSTODY JUDGMENTS IN THE TURKISH COURTS

1. WITHIN THE FRAMEWORK OF THE CONVENTION OF 1961 CONCERNING THE POWERS OF AUTHORITIES AND THE LAW APPLICABLE IN RESPECT OF THE PROTECTION OF MINORS

The European Convention, to which Turkey has acceded, is aimed at the recognition and enforcement of foreign custody judgments in a rapid and effective way, and at ensuring the prompt return of children (Celikel, 1997-1998). For the Convention to be applicable, it is enough that a custody judgment has been given by a court of a contracting state and is sought to be enforced in a court of a contracting state (Article 7). According to the Convention, a custody decision is a decision determining where a child is going to live and who may have a personal relationship with the child (Article 1/c). Decisions regarding the custodian parent's rights and responsibilities with regard to the child's property are outside the scope of the Convention. 
Articles 8 and 9 of the Convention deal with the enforcement of judgments when an improper removal of a child occurs. In addition to this, Article 10 provides for other possibilities with regard to the enforcement of custody judgments. Also, improper removals which do not satisfy the conditions of Articles 8 and 9 are subject to Article 10. Within the scope of Article 10/1/a, if it is concluded that the outcomes of the judgment obviously contradict the main family and child law principles of the state which is being asked to enforce the judgment, enforcement may be refused. This provision is very important for our study, because the Turkish courts refuse the enforcement of joint custody judgments, basing their decisions on this provision.

\section{WITHIN THE FRAMEWORK OF THE CPIPL}

The recognition and enforcement procedure is subject to the CPIPL if a foreign custody judgment is outside the scope of an international treaty (Nomer \& Şanll, 2010) ${ }^{10}$ So, for example, a judgment given by a court of a state which is not party to the European Convention will be subject to the procedure of the CPIPL.

In Turkish law, decisions on 'divorce, lineage, or name' which have declarative effect are to be recognized (Şanll, 1996). However, if the decision also requires implementation, recognition would not be sufficient and enforcement is required (Şanll, 1996). In this way, both the res judicata effect of the foreign judgment and the implementation of the judgment by the executive organs of the state are ensured. This division is critical because the conditions for recognition and enforcement differ: within the context of the CPIPL, all requirements for enforcement other than reciprocity have to be satisfied for the recognition of a judgment (Article 58/1). Therefore, declarative decisions are recognized in Turkey even if there is no reciprocity between Turkey and the other state.

After the pre-conditions for enforcement are met (i.e. the judgment has been given by a court and there has been a final judgment), the first main condition for enforcement under Article 54/1/1 of the CPIPL is that there should be reciprocity between the Turkish state and the state of the court which rendered the judgment. ${ }^{11}$ The reciprocity might be established by an international convention, a provision of law or the de facto situation. ${ }^{12}$ If there is a convention, the recognition and enforcement conditions are determined within the context of the convention. If the provisions of the convention are stronger than the provisions of the Turkish CPIPL, the conditions stated in the CPIPL will apply (Şanll, 1996). The second condition for enforcement is that the subject matter of the foreign judgment should not be a subject on which the Turkish courts have exclusive jurisdiction. For the exclusive jurisdiction cases, the Turkish courts have the sole authority and there is always a 
competent court in Turkey (Şanl, 1996). An example of exclusive jurisdiction is the jurisdiction over immovable property located in Turkey. However, divorce and custody cases are not among the exclusive jurisdiction cases, and foreign judgments on these issues may be enforced in Turkey. Therefore, the enforcement of foreign custody judgments fulfils this condition. The third condition is that there should be a connection between the dispute and the foreign state that rendered the judgment which is subject to enforcement in Turkey. For divorce cases, this connection exists, for example, when one of the parties is a citizen of the state where the judgment was made. Another condition for enforcement is that the party against whom the enforcement is sought should have been summoned to the foreign court with due diligence and should have been duly represented. So, all the rights of that party to defend the claim should have been protected.

\section{PUBLIC POLICY INTERVENTION IN THE ENFORCEMENT OF FOREIGN JOINT CUSTODY JUDGMENTS}

The condition for enforcement which has the main importance for our study is that the foreign judgment should not contradict Turkish public policy. Judgments that are against basic ethics, rights, or freedoms might be approached within this framework.

When considering the public policy intervention, its exceptional characteristic should be considered (Aybay and Dardağan, 2008). The primary intention is to acknowledge the foreign court's judgment as far as possible. So, if the part of the judgment that is against public policy can be isolated, the rest of the judgment will be enforced. For example, the divorce part of the judgment may be recognized, but if the custody part restricts the personal relationship of one of the parents with the child with no reasonable grounds, this may not be enforced. ${ }^{13}$ Partial enforcement has a key role for joint custody judgments. Because of public policy, the enforcement of the custody part may be rejected while the divorce part of the judgment is recognized. In this case, it does not matter whether the application for enforcement is made under the Turkish CPIPL or the European Convention. ${ }^{14}$

The essence of the Turkish courts' approach is as follows: since joint custody is not possible under the Turkish CC, and because custody is a subject directly related to public policy, applications to enforce joint custody decisions should be refused. This is because Article 336 of the CC requires that custody of a child is granted to only one of the parents after divorce. Therefore, Turkish courts assess joint custody as a subject manifestly incompatible with the fundamental principles of Turkish family law and, relying on Article $10 / 1 / \mathrm{a}$ of the European 
Convention (or Article 54/1/c of the CPIPL where the Convention is not applicable), reject a claim for enforcement.

Decisions on the non-enforcement of foreign joint custody judgments have been made either unanimously or by a large majority. Among the dissenting opinions ${ }^{15}$ attached to the decisions given by large majority, it is emphasized that public policy intervention should not come into question automatically only on the grounds that the foreign law has a different understanding from Turkish law. Therefore, although joint custody is not accepted by Turkish law, it is not obviously against public policy. In this framework, public policy intervention may only occur when there are clear contradictions with fundamental rights and freedoms, principles accepted in international law, main ethical principles, basic principles of Turkish law, and values which may not be sacrificed. Dissenting opinions also say that the grounds for refusing enforcement are clearly settled under Articles 9 and 10 of the European Convention, and they have also emphasized that enforcement may be refused when the results of the judgment do not comply with the family and child law principles of the country where the enforcement is demanded.

QUESTIONING THE PERTINENCE OF PUBLIC POLICY INTERVENTION

We absolutely agree with the reasoning of the dissenting opinions. Public policy intervention should not automatically occur only because the foreign judgment has a different understanding from the law of the forum in which enforcement is demanded (Öztekin Gelgel, 2005). Only if there are intolerable infringements of public conscience, of fundamental ethical principles or of the values of the society, should the public policy exception come into question (Nomer \& Şanll, 2010; Gürzumar, 1999). The rules on conflict of laws also require such an approach. Hence, unless it can be shown how joint custody may go against public policy, the enforcement should not be refused (Ruhi, 2003). On the other hand, accepting that joint custody is automatically a subject directly connected to public policy is also against the principles of the conflict of laws (Öztekin Gelgel, 2005). Each case should be assessed individually when considering public policy intervention (Gürzumar, 1999).

Moreover, Article 336/2 of the CG, which is the main reason for refusing the enforcement, states that 'the judge can entrust the custody to one of the spouses if the joint life is terminated or the separation occurs'. In terms of grammatical interpretation, it is claimed by legal writers that, since the provision has not been written as an imperative, 
the judge has a discretionary power (Nomer and Şanll, 2010; Giray, 2010). When making a custody decision, the judge considers the requirements of society, the relationship between the spouses, and, foremost, the interests of the child (Koçhisarlıoglu, 2004). In essence, it is inappropriate to refuse the enforcement of the foreign judgment on the basis of public policy merely because that foreign judgment is different from a non-obligatory provision that grants the judge a discretionary power. It is also important to note that, even if the provision was written as an imperative, it would not be possible to say that every foreign judgment that is contrary to the imperative rules of Turkish law should be directly subject to the public policy intervention (Aybay and Dardağan, 2008).

Finally, we are of the opinion that, since custody is shared between the spouses during the marriage, it is not reasonable automatically to prevent joint custody after divorce on the basis of public policy.

THE CHILD'S BEST INTERESTS AS A RELEVANT FACTOR IN DECIDING ON THE ENFORCEMENT OF JOINT CUSTODY JUDGMENTS

Setting aside the other possible situations that may trigger the public policy exception (e.g. infringement of fundamental defence rights), we propose an alternative assessment for deciding on the enforcement of foreign joint custody judgments, which is based upon the child's best interests. According to this assessment method, the public policy exception may prevent enforcement when the joint custody judgment contravenes the child's best interests. The child's interests are also of importance, and play a critical role, in domestic custody judgments of the Turkish courts. ${ }^{16}$ For example, in order to protect the child's interests, custody may not be entrusted to a parent who is a drug addict or an alcoholic. This approach based on the child's well-being can also be a way to assess public policy intervention in the enforcement of joint custody judgments. Therefore, foreign joint custody judgments should not be automatically rejected without applying this assessment method. Enforcement of such a judgment may be rejected on the grounds of public policy if the judgment conflicts with the child's interests.

The first legal basis for our suggestion that the child's interests should be the main factor when deciding on the enforcement of joint custody judgments may be Article 41 of the Turkish Constitution (Öztekin Gelgel, 2005). In the paragraph following and attached to Article $41,{ }^{17}$ it is noted that every child has the right to have and maintain a personal and direct relationship with his/her parents unless this is contrary to his/her important interests. For this reason, 
consideration of the child's interests when making an enforcement decision on a joint custody judgment has even got a constitutional basis. Thus, the public policy exception might be relied on when the enforcement of the joint custody judgment is contrary to the child's interests, because it is then also contrary to a constitutional principle (Öztekin Gelgel, 2005). Therefore, the Turkish courts' decisions which do not include an examination of whether the foreign joint custody judgment is in harmony with the child's interests can also be criticized from a constitutional point of view.

The second legal basis for the interests of the child criterion is Article $3 / 1$ of the United Nations Convention on the Rights of the Child, to which Turkey is a party. Article $3 / 1$ of the Convention emphasizes that in every act implemented by public or private organs, such as courts or administrative authorities, the interests of the child should have a primary role. Moreover, under paragraphs 1 and 3 of Article 9, the child's interests are, once again, determined to be the leading factor when making a decision about the relationship between the child and the parents (Huysal, 2005). These articles of the Convention can be the second legal basis for our proposed assessment.

The criterion that a decision is in the child's interests is relevant for custody in many provisions in Turkish substantive law. For example, under Article 182/2 of the CC, a judge making a custody decision in a divorce case gives priority to the child's interests. The child's interests also have a privileged position in procedural law (Huysal, 2005). The objectivity of the judge, which is one of the main principles of Turkish procedural law, is set aside when the subject is the child's well-being. In custody matters, the Turkish judge acts on their own motion, and takes the necessary precautions to protect the child's interests. For the purpose of determining whether the joint custody judgment is in conformity with the child's interests, the judge may analyse the merits of the case (Demir Gökyayla, 2001), as an exception to the prohibition of révision au fond. ${ }^{18}$ If the judge reveals that there is a situation which is in conflict with the child's interests, they may refuse the enforcement on the grounds of public policy.

DETERMINING WHETHER THE JOINT CUSTODY JUDGMENT IS IN THE INTERESTS OF THE CHILD OR NOT

After stating that public policy intervention is possible when the judgment is not in the child's interests, we need to consider how this situation can be identified. This subject is of particular importance in international cases, because in such cases it is likely that the spouses are in different countries, so the custody judgment has a significant role in maintaining the connection between parent and child. 
According to the supporters (for details see, Barnes, 1999) of joint custody, children feel more secure and confident when they see that their parents decide together on things which are important for their lives. ${ }^{19}$ They conclude that their parents are still able to communicate and are in dialogue despite the divorce. Not only the sense of belonging, but also love and feelings of loyalty between the child and the parents, are strengthened. The child perceives that he/she has an identity in the family and does not feel left alone or abandoned. This may help the child recover from the divorce more effectively.

Similarly, 33 studies ${ }^{20}$ carried out between 1982 and 1999 reveal that joint custody led to better outcomes in the child's adjustment to the divorce than sole custody. In this study, criteria such as self-esteem, emotional, and behavioural adjustment, family relationships and adjustment to divorce were used, and both joint legal and joint physical custody were examined (Bauserman, 2002). In some cases, children who were under joint custody were in the same position as children of parents who had never divorced. However, in terms of academic success, children who were under joint custody did not have a similar position to children of parents who had never divorced.

Joint custody positively encourages the spouse in the better financial position to pay alimony (Barnes, 1999; Hardcastle, 1998-1999). Researchers explain this positive encouragement by the 'monitoring' theory. ${ }^{21}$ The 'monitoring' theory claims that when a person observes how the alimony is spent, and keeps a right to intervene as necessary, he/she is more willing to pay the alimony on time. Prompt and regular alimony support is critical for the child's living environment and for his/her current and future well-being.

Another benefit of joint custody is related to the father. It is often the mother who has custody under a sole custody decision. When custody is entrusted to the mother, and the father is only granted a right to visit the child, an artificial relationship is created between the father and the child (Barnes, 1999). This is because the father and the child often spend leisure time together, and engage in more enjoyable activities than everyday regular activities. Therefore, the father does not play a parental role in the child's life. Instead, he becomes a fun 'friend'. His identity as a father may dissolve and become extinct over time. Low selfesteem and authority in his primary fatherhood role causes the father to visit the child less frequently, and even to terminate the relationship entirely. Joint custody can avoid the possibility of a dissolved fatherhood identity. When the father actively plays a role in the child's everyday activities such as, for example, taking decisions on the child's education, extra-curricular activities, social and artistic development, etc., he will be holding on to his identity as a father. The more roles the father plays in the child's life, the more he becomes willing to participate in his child's upbringing (Barnes, 1999). When the children of divorced 
parents have stable and ongoing relationships with their fathers, they are less likely to feel abandoned by their fathers and are consequently more likely to become socially confident.

Despite the aforementioned benefits, joint custody has also been criticized. According to some scholars, joint custody restricts the mother's role and identity in the child's physical and emotional behaviour (Barnes, 1999; Schulman \& Pitt, 1982). Moreover, with joint custody, trips back and forth to both parents' homes may weaken the child's self-identity in his/her environment and his/her relationships with the family members. Also, the child may risk not knowing his/her parents at the desired level (Barnes, 1999).

No one can simply claim that joint custody always generates positive results. Some scholars argue that, while joint custody generally produces more adaptable children, it sometimes does not make any substantial difference compared to the effects of sole custody, as reported in earlier research (Hardcastle, 1998-1999). Joint custody does not always generate positive results for the child, and nor has it always worked in the best interests of the child. Joint custody can be a good alternative for parents who are in good communication and working in harmony. For example, parents who can keep a respectful relationship, by setting aside their personal conflict for the sake of their child and sharing the responsibility of being a parent, are better off having joint custody (Kurki-Suonio, 2000; Hardcastle, 1998-1999; Schulman and Pitt, 1982). In such cases, the parents can shape the child's life in a similar way to the way they would do it if they were married.

However, such an ideal cooperation between divorced parents is rare. In a study (Steinman et al, 1985) of 48 joint custody families, while 13 families were rated as 'successful', 20 families were found to be 'stressed' and 15 families 'failed'. The study concluded that the parents in the successful families had the common characteristics of being respectful towards each other, believing that the other parent was also a good parent, having self-esteem, and being open to help (Steinman et al, 1985). In cases where the parents had hostile emotions towards each other, or believed that the other parent was not a good parent, joint custody failed (Buchanan and Jahromi, 2008; Steinman et al, 1985). Similarly, for families with a history of intra-family violence who were still in conflict or families on whom joint custody was forced by the court instead of being mutually agreed by the parents, joint custody generated negative outcomes for the child (Steinman et al, 1985).

Despite the negative outcomes of a divorce, a joint custody judgment is an appropriate alternative for a family where the parents can effectively communicate with each other and act jointly for the benefit of the child. A joint custody judgment for such a family is for the benefit of the children. The children will have the chance of observing their parents' joint support in some critical decisions having an impact on their lives, 
which would be similar if there was intra-marriage custody. In such a case, if the foreign court has reached the custody judgment after assessing all the dimensions of the case and has concluded that a joint custody judgment is in the interests of the child, it is not fair to refuse the enforcement of such a judgment on the grounds of public policy (Giray, 2010). Hence, in many jurisdictions, such as France (Parkinson, 2011), Switzerland (Singer, 2008), and Australia (Rhoades and Boyd, 2004), post-divorce parenting arrangements such as joint responsibility or alternating residence are ordered after considering the best interests of the child. Therefore, enforcement of such a judgment, which protects the child's best interests because those interests are paramount, should not be refused on the grounds of being against public policy.

In Turkish law, one principle in enforcement cases is the prohibition on the courts reviewing the merits (révision au fond) of foreign judgments. However, while determining public policy intervention, the Turkish judge may analyse some details of the case that are not clear from reading only the final paragraph of the foreign judgment (Nomer and Sanl, 2010). In doing this, the judge may analyse the family structure and the parent's relationship with the child when deciding on the enforcement of custody judgments. However, the analysis should be bounded by the aim of revealing the child's best interests. So, for the purposes of assessing the child's interests, the Turkish judge may evaluate some details of the case.

Considering that the judge has this power, it is not fair to refuse the enforcement of joint custody judgments only on the grounds that joint custody is not accepted in Turkish domestic law or that custody is a subject directly related to public policy. Following the analysis of the family structure and the parents' relationships with the child, a refusal of the enforcement on the grounds of public policy might be discussed, but only if the judge concludes that the joint custody judgment is in conflict with the child's best interests.

WHAT HAPPENS WHEN THE ENFORCEMENT OF THE FOREIGN JOINT CUSTODY JUDGMENT IS REFUSED?

In cases where the foreign court has rendered a divorce judgment accompanied by a custody judgment, and an application is made for these judgments to be enforced by the Turkish court, a partial effect is given to the foreign judgment as noted above. In these cases, if all the conditions are met, the divorce judgment is recognized whereas the custody judgment can be rejected. If we maintain our belief that the enforcement of the joint custody judgment should be refused when it contravenes the child's best interests, a conflict may occur in practice that we discuss below. 
As a result of the partial enforcement, the divorce judgment has a binding, substantive effect in Turkey. For example, if one of the parties has Turkish citizenship, the civil registry is informed about the enforcement judgment in order to make the relevant amendments. However, since the custody part of the foreign judgment is not enforced, the question arises of how the custody issues should be resolved. Such a suspension in the custody arrangement should not be accepted, considering the child's best interests. How does the Turkish judge decide on this?

In Turkish domestic law, as confirmed by the Court of Cassation, the judge's decision is not confined to the claims made on custody issues, and the judge may act on their own motion. This power of the judge is included in many provisions of the CC (Huysal, 2005; Şanl, 1996). When a partial effect is given to the foreign judgment, the Turkish judge discovers that there is no decision on custody. Therefore, a custody decision is required by the judge's own motion (Sanlı, 1996). Taking their authority from Article 351 of the CC, which states that 'upon a change in circumstances, the precautions with regard to the child's protection should be adopted to the new circumstances', the judge should find an appropriate solution for the custody of the child. It is also possible for the parties to ask for the custody to be re-arranged. However, such an act of the parties does not have the characteristics of a separate case: it is only a notification or warning addressed to the judge (Şanll, 1996). So, the parties are not required to file a separate suit.

Within the context of Article 11/3 of the European Convention, if enforcement of a judgment on custody is refused, the administrative authority of the state where the enforcement is demanded may apply to the competent authorities. The administrative authority may ask the competent authorities to rule on the personal relationship between the child and the party requesting enforcement. Therefore, if a Turkish judge refuses enforcement which is requested under the CPIPL or the European Convention, they should make a decision regarding the child's custody and fill in the gap that occurred as a result of refusing the enforcement. They should first consider the child's best interests and find the best decision that is compatible with the individual specific case, recognizing that each family is different from other families. A general rule that is applicable to all custody cases cannot be provided. The decisions should instead be individual. The judge will probably follow the custody approach of the Turkish domestic law (Article 336/2 of the CC), and entrust custody to one of the parents.

It is obvious that this procedure takes a long time, hurts the parties, leaves the child's custody ambiguous for an indefinite period of time, and is therefore disadvantageous, mainly to the child. When rejecting a claim for the enforcement of a joint custody judgment, the judge should be aware that a substantial chain of problems is waiting for 
them. For example, the parent who has had shared rights regarding the child will lose his/her rights entirely and become a completely noncustodian parent. Assuming that such a parent is a foreign national, he/ she will have no custody rights within the boundaries of Turkey. Such an outcome is contrary to the justice of the conflict of laws principles when the joint custody judgment is for the benefit of the child.

\section{APPLICATION OF THE HAGUE CONVENTION ON THE CIVIL ASPECTS OF INTERNATIONAL GHILD ABDUCTION IN TURKEY}

Wrongful removal of the child might be another area of conflict in custodial issues. The Hague Convention on International Child Abduction is an important instrument for granting relief in this area.

The Hague Convention applies to cases where a child who has habitual residence in a contracting state is wrongfully removed and retained in the territory of another contracting state (Article 3). The most important aim of the Hague Convention (Article 16) is to ensure the expeditious return of the child to his habitual residence, and the Convention does not deal with issues such as who should be granted custody of the child. The Turkish Republic is a signatory state of the Convention $^{22}$, and a code (Code $26720^{23}$ ) which regulates the procedures for applying the Convention entered into force in 2007 in Turkey.

If the application of the Hague Convention is approached from the perspective of this article, which is the enforcement of joint custody judgments, the following possibility might arise. Let us assume that the two parents have joint custody of the child and that one of them has wrongfully removed and retained the child in Turkey. The other parent has filed a suit before the Turkish court to demand the return of the child to the child's habitual residence. Under these circumstances, Turkish courts are obliged to decide on the return of the child first, and this is both accepted in court practice ${ }^{24}$ and stipulated under the Code 26720, Article 15/1. The Turkish courts ${ }^{25}$ consider the removal of the child as 'wrongful' when such a removal is in breach of the other parent's joint custody rights (pursuant to Article 3/a of the Hague Convention). So, the Turkish courts take notice of a parent's 'joint' custody rights, but only in determining whether the removal of the child was wrongful or not. In this regard, there is no such requirement for recognition and/or enforcement of a foreign custody judgment (as emphasized in the decisions of the Supreme Court ${ }^{26}$ ). On the other hand, the foreign custody judgment might be 'considered' pursuant to Article 14 of the Convention. In an analysis (Akıncı and Gökyayla, 2010: 276), it has been alleged that 'direct recognition of the foreign custody judgment has been enabled in a child return case irrespective of the fulfilment of the conditions indicated in CPIPL'. However, direct 
recognition of a 'joint' custody judgment would not be possible according to the Turkish courts' general tendency to refuse enforcement of such judgments. As a result, if the conditions for the return of the child are met, the child is returned irrespective of the enforcement of the joint custody judgment (Article 16 of the Hague Convention).

If the return of the child is refused by the Turkish court, only then does it become possible for the court to deliver an enforcement judgment on custody (Code 26720, Article 12/1). For instance, if the 1-year time limit (Convention Article 12) for demanding the child's return has been missed and the Turkish court has decided that the child has settled in his/her new environment, or if it has been concluded that there are reasons to refuse the return under Article 13/b of the Convention, the child's return is refused. As a result of this refusal, it becomes possible to hear the case for the enforcement of a joint custody judgment. However, considering the general approach of the Turkish courts, one would assume that the enforcement of the joint custody judgment would be refused. In this regard, since there is a need for a custody judgement to be handed down, the judge is entitled to render a custody judgment on their own motion (Huysal, 2005; Şanlı, 1996).

In this framework, it might be appropriate to look at how the Turkish courts interpret the grounds for refusal of return contained in Article 13 of the Hague Convention. The inferior courts sometimes drift away from the general principle that the provision should be subject to a restrictive interpretation, and find some weaker grounds for refusing to order the return of the child. For instance, the child being young and needing his/her mother has been found by the inferior courts to be a reasonable ground for rejection. The Supreme Court has reversed these judgments, ${ }^{27}$ claiming that refusing to make an order for the return is only possible in a case where there are serious and obvious dangers for the child's physical and/or psychological development. On the other hand, it has been concluded that a 2-year-old child should not be returned to his/her father because of the insensitive attitude of the father towards the child. ${ }^{28}$ It can be concluded that, when the grounds for refusal in Article 13 of the Convention are being interpreted, the Supreme Court both requires consideration of the best interests of the child and stipulates that return should be refused only in cases where there is a very serious danger to the child, such as physical or sexual abuse of the child, famine, epidemic, or a state of war in the country of the child's habitual residence. ${ }^{29}$

\section{CONCLUSION}

In this study, the approaches of the Turkish courts to the enforcement of joint custody judgments given by foreign courts have been criticized. 
We noted that the enforcement procedure is carried out under the principles of the CPIPL or the European Convention; the Turkish courts may refuse enforcement by either (i) interpreting Article 336 of the CC to mean that custody should be entrusted to only one of the parents or (ii) assuming that custody is a subject directly connected to public policy.

In our opinion, this rationale of the Turkish courts complies neither with the methodology of public policy intervention as it relates to the conflict of laws nor with the understanding that public policy intervention should only occur in intolerable circumstances, such as when a decision is clearly against the fundamental ethical principles of a society. It is not fair to assume that 'custody' is a subject directly connected to public policy, since every public policy intervention should be assessed independently for the individual case. In this article, we have questioned the plausibility of the notion that 'a joint custody judgment is against public policy', especially when the best interests of a child of divorced parents are considered. In cases where the parents are able to communicate effectively and to work in collaboration in a civilized and safe manner for the child, such co-operation is advantageous for the child, so public policy intervention should not occur. The joint custody judgment should be enforced, and the connections between the child and the parents should be protected in international cases, where there might be substantial distances involved. Yet, when the outcome of the judge's assessment implies that the joint custody judgment is in conflict with the child's best interests, then the public policy intervention might be a reasonable ground for refusing the enforcement. After such a rejection, since the custody issue is obscure, the Turkish judge ought to find the most appropriate solution that best guarantees the child's well-being.

\section{NOTES}

\footnotetext{
${ }^{1}$ If this will be for the benefit of the child, the relationship between the child and the noncustodian parent may be restricted for a certain period of time: Sup. Court, 2. Chamber, E. 823/K. 8927, 7 June 1992 (Şener, 1994: 201-02). When a decision is given about personal relationships, the best interests of the child should have the principal role. Therefore, it is not appropriate for a child to stay with his/her father 10-15 days a month since it may have a negative effect on the child: Sup. Court, 2. Chamber, E. 1992/10333, K. 1992/10669, 3 November 1992. A non-custodian father and his child should have a reasonable amount of personal time together: Sup. Court, 2. Chamber, E. 1992/10104, K. 1992/10568, T., 3 October 1992 (Şener, 1994: 205).

${ }^{2}$ Turkish Official Gazette, 27.01.1995-22184. Date into force: 2 September 1990.

${ }^{3}$ Sup. Court General Council, E. 2003/2-513, K. 2003/521, 1 October 2003: www.turkhukuksi tesi.com (last visited: 3 January 2012); Sup. Court, 2. Chamber, E. 2005/12496, K. 2005/15273, 8 November 2005: www.turkhukuksitesi.com (last visited: 3 January 2012); Sup. Court, 2. Chamber, E. 2003/1779, K. 2003/2976, 6.3.2003: www.turkhukuksitesi.com (last visited: 3 January 2012).

${ }^{4}$ A 4-year-old child needs to be taken care of by the mother. There is no clear evidence that staying with the mother will have a negative impact on the child's physical, intellectual, or moral improvement. The mother being non-Muslim and non-Turkish cannot be accepted as reasonable
} 
grounds to claim that the child's intellectual and moral development will be impeded: Sup. Court, General Council, E. 1992/2-763, K. 1993/117, 17 March 1993. The essence of custody is to protect the child and secure his/her future. Therefore, every possible situation which may hamper the child's physical and psychological development should be assessed: Sup. Court, General Council, E. 2008/2-247, K. 2008/247, 12 March 2008. Since the father's disloyalty and adultery may have a negative impact on the child's mental and ethical improvement, custody was entrusted to the mother: Sup. Court, 2. Chamber, E. 1984/9897, K. 1984/10089, 4 December 1984. A custody demand by the father was rejected on the grounds that he was an alcoholic: Sup. Court, General Council, E. 2010/2-259, K. 2010/329, 16 June 2010. Entrusting custody to the child's stepmother following the judgment of S-Hertogenbosch District Court, the Netherlands has been found by a Turkish court to be against the law: Sup. Court, E. 2004/9168, K. 2004/10346, 21 September 2004. Considering the interests of the child, custody has been entrusted to the mother when the father uses violence against the mother: Sup. Court, General Council, E. 2003/2-513, K. 2003/521, 1 October 2003: www.turkhukuksitesi.com (last visited: 3 January 2012).

${ }^{5}$ Luxembourg, 20 May 1980. Turkish Official Gazette, 2 November 1999-23864.

${ }^{6}$ Concluded 5 October 1961. Turkish Official Gazette, 21 November 1983-17966.

${ }^{7}$ Entry into force: 1 December 1983. Turkish Official Gazette, 15 February 2000-23695.

${ }^{8}$ Strasbourg, 15 May 2003. Turkish Official Gazette, 17 November 2011-28115.

${ }^{9}$ Fathers, especially, complain of parental alienation syndrome, saying that they want to participate in child-raising issues and see their children more often and more easily. Therefore, fathers come together and try to express their demands on websites such as www.ortakvelayet.com (www. jointcustody.com) or www.bosanmisbabalar.com (www.divorcedfathers.com).

${ }^{10}$ Bilateral agreements on the recognition and enforcement of foreign judgments are not included here.

${ }^{11}$ With regard to the recognition and enforcement of foreign judgments, Turkey has signed bilateral agreements with many countries among which are Italy, Romania, Tunisia, Poland, Algeria, Austria, Iraq, Azerbaijan, People's Republic of China, Georgia, Albania, Kazakhstan, Macedonia, Egypt, Croatia, Moldova, Kuwait, and Tajikistan. It should be borne in mind that recognition and enforcement of custody judgments rendered by courts of states that are party to the European Convention will be assessed under that Convention.

${ }^{12}$ Since the court of first instance had not researched thoroughly the legal provisions and actual situation with regard to the enforcement of foreign judgments in North Carolina, USA, the judgment of the court of first instance was rejected: Sup. Court, 2. Chamber, E. 2010/11237, K. 2011/2718, 16 February 2011, www.kazanci.com (last visited: 12 January 2012).

13 Sup. Court, 2. Chamber, E. 2006/2773, K. 2006/9267, T.12.6.2006, www.kazanci.com (last visited: 23 December 2011): a judgment of the Michigan State Court was partly enforced; while the divorce part was enforced, the custody part, which granted one of the parents a very limited right, was rejected on the grounds of being contrary to public policy.

${ }^{14}$ For instance, the enforcement of joint custody judgments has been refused by the Turkish courts on the grounds of being contrary to public policy: divorce and joint custody judgment of Fürth Law Court, Germany: Sup. Court, 2. Chamber, E. 2003/3784, K. 2003/4670, 2 April 2003. Divorce and joint custody judgment rendered by the Amsterdam Court, the Netherlands: Sup. Court, 2. Chamber, E. 2004/13947, K. 2004/15854, 27 December 2004. Divorce and joint custody judgment given by the Michigan State Court, USA: Sup. Court, 2. Chamber, E. 2006/2773, K. 2006/9267, 12 June 2006. The Rotterdam Court in the Netherlands rendered a judgment on the divorce of a couple who had dual Turkish and Dutch citizenship and ordered custody of the two children to be shared between the parents. Although the children would stay with the mother, the father was entitled to have contact with the children during the summer holidays and on special days and birthdays. An application for enforcement of the Rotterdam Court's judgment was made to the Turkish court: Sup. Court, 2. Chamber, E. 2004/12285, K. 2004/13680, 22 November 2004. Divorce and joint custody judgment of the Hagen Local Court, Germany: Sup. Court, 2. Chamber, E. 2006/6824, K. 2006/13638, 10 October 2006. Demand for the enforcement of a divorce and joint custody judgment of Wiesloch Local Court, Germany: Sup. Court, 2. Chamber, E. 2003/4019, K. 2003/5500, 15 April 2003. For the decisions of the Turkish courts see www.kazanci.com (last visited: 24 December 2011).

${ }^{15}$ Sup. Court, 2. Chamber, E. 2004/13947, K. 2004/15854, T. 27 December 2004; Sup. Court, 2. Chamber, E. 2006/2773, K. 2006/9267, T., 12 June 2006; Sup. Court, 2. Chamber, E. 2004/12285, K. 2004/13680, T. 22 November 2004; Sup. Court, 2. Chamber, E. 2006/6824, K. 2006/13638, T., 10 October 2006. Details of the judgments can be found at www.kazanci.com (last visited: 24 December 2011). 
${ }^{16}$ A foreign judgment which entrusts the custody of the child to the father and prohibits the mother from having any kind of personal relationship with the child has not been found to contradict Turkish public policy: Sup. Court, 2. Chamber, E. 1997/675, K. 1997/1633, 17 February 1997, www.kazanci.com (last visited: 12 January 2012).

${ }^{17}$ Turkish Constitution Article 41 - Protection of the Family and Children's Rights: (Additional Paragraph: 7/5/2010-5982/4 Article) Every child has the right to adequate protection and care and the right to have and maintain a personal and direct relationship with his/her parents unless it is contrary to his/her privileged interests.

${ }^{18}$ The Sonderberg Court, Denmark entrusted the custody of Kenneth, Tobias, and Yannick to their father, terminating the custody rights of the mother. Enforcement of the judgment was demanded from the Turkish courts, relying on the European Convention. Under Article 9/3 of the Convention, the merits of foreign judgments cannot be reviewed. For this reason, the judge in the enforcement court cannot review the procedural, substantial, or legal determinations of the foreign court. Therefore, it cannot be seen as a reasonable ground for refusing enforcement that the foreign court did not consider the compulsory provisions of Turkish law or applied them in an inaccurate way: Sup. Court, 2. Chamber, E. 2004/10683, K. 2004/13120, 4 November 2004, www. kazanci.com (last visited: 27 December 2011).

${ }^{19}$ In a joint custody study, it was concluded that joint custody benefits children in three ways: children get a clear message that they are loved and wanted by their parents; they feel that they are important for their families and observe their parents' endeavours to take care of them jointly; and those children who have physical connections with their parents think that they have psychological permission to love and to be with their parents (Barnes, 1999: 621-22).

${ }^{20}$ For the details of the studies see Bauserman, 2002: 94-98.

${ }^{21}$ For details see Barnes, 1999 and Hardcastle, 1998-1999.

22 Turkish Official Gazette, 15 February 2000-23965.

${ }_{23}$ Turkish Official Gazette, 4 December 2007-26720.

${ }^{24}$ For instance, Sup. Court, 2. Chamber, E. 2010/ K. 2010, 21 June 2010: www.kazanci.com.tr

${ }^{25}$ For instance, Trabzon 3. Court of First Instance, E. 2003/470, K. 2004/3212, 11 March 2004: Akıncı and Gökyayla, 2010: 238, fn. 301.

${ }^{26}$ For instance, Sup. Court, 2. Chamber, E.2006/17627, K. 2007/12722, 27.9.2007: www.kazanci. com.tr

${ }^{27}$ For instance, Sup. Court, 2. Chamber, E. 2004/10536, K. 2004/11797, T., 14 October 2004: www.kazanci.com.tr; Sup. Court, 2. Chamber., E. 2006/17797, K. 2006/14657, T., 31 October 2006.

${ }^{28}$ Sup. Court General Council, E. 2010/2-628, K. 2010/693, T., 22 December 2010.

${ }^{29}$ Sup. Court, 2. Chamber 14.10.2004, 10536/11797: Akıncı and Gökyayla, 2010: 287, fn. 335.

\section{REFERENCES}

Akıncı, Z. and Gökyayla, C. D. (2010). Milletlerarast Aile Hukuku [International Family Law], İstanbul: Vedat.

Aybay, R. and Dardağan, E. (2008). Uluslararast Düzeyde Yasalann Cathsmast (Kanunlar İtilafi) [Conflicts of Law at an İnternational Level], Istanbul: Istanbul Bilgi Üniversitesi.

Barnes, S. N. (1999). 'Strengthening the father-child relationship through a joint custody presumption', Willamette Law Review 35 (3), 601-28.

Bauserman, R. (2002). 'Child adjustment in joint-custody versus sole-custody arrangements: a meta-analytic review', Journal of Family Psychology 16 (1), 91-102.

Buchanan, C. M. and Jahromi, P. (2008). 'A psychological perspective on shared custody arrangements', Wake Forest University Law Review 43 (2), 419-39.

Celikel, A. (1997-1998). Yabanct mahkemelerden verilen velayete iliskin kararlann tanınmast ve tenfizi [Recognition and Enforcement of Foreign Custody Judgments], Milletlerarası Özel Hukuk Bülteni, 17 (1-2), 107-16.

Demir Gökyayla, H. (2001). Yabanc Mahkeme Kararlannın Tanınması ve Tenfizinde Kamu Düzeni [Public Policy in the Recognition and Enforcement of Foreign Judgments], Ankara: Seçkin.

Fehlberg, B., Smyth, B., Maclean, M. and Roberts, C. (2011). 'Legislating for shared time parenting after separation: a research review', International Journal of Law, Policy and the Family 25 (3), 318-37. 
Giray, F. K. (2010). Milletlerarası Özel Hukukta Kaçı nlan veya Alkonan Cocuklann İadesi [Return of the Abducted or Retained Children in Private International Law], İstanbul: Beta.

Gürzumar, A. (1999). 'Türk devletler özel hukuku açı sı ndan boşanma davalannda kamu düzeninin etkileri [Effects of public policy in divorce cases from the perspective of Turkish private international law]', Milletlerarast Özel Hukuk Bülteni. Year 19 (1-2), 21-54.

Hardcastle, G. (1998-1999). 'Joint custody: a family court judge's perspective', Family Law Quarterly 32, 201-19.

Huysal, B. (2005). Devletler Özel Hukukukunda Velayet [Custody in Private International Law], İstanbul: Legal Yayıncilık.

Koçhisarlığlu, C. (2004). Boşanmada Birlikte Velayet ve Yasantn Aşılmast [Joint Custody in Divorce and Going Beyond the Code], Ankara: Turhan.

Kurki-Suonio, K. (2000). 'Joint custody as an interpretation of the best interests of the child in critical and comparative perspective', International Journal of Law, Policy and the Family 14, 183-205.

Melli, M. S. and Brown, P. R. (2008). 'Exploring a new family form-the shared time family', International Journal of Law, Policy and the Family 22, 231-69.

Nomer, E. and Şanll, C. (2010). Devletler Hususi Hukuku [Private international law], İstanbul: Beta.

Öztekin Gelgel, G. (2005). Devletler özel hukukunda velayet, çocuk kaçımalan, evlat edinmeye ilişkin problemler [Matters Regarding Custody, Child Abduction and Adoption in Private International Law], İstanbul: Ticaret Üniversitesi Sosyal Bilimler Dergisi, 119-48.

Parkinson, P. (2011). Family Law and the Indissolubility of Parenthood, New York: Cambridge University Press.

Piconto Novales, T. (2012). 'The equality right of parents and the protection of the best interest of the child after partnership breakdown in Spain', International Journal of Law, Policy and the Family 26 (3), 378-400.

Rhoades, H. and Boyd, S. B. (2004). 'Reforming custody laws: a comparative study', International Journal of Law, Policy and the Family 18, 119-46.

Ruhi, A. C. (2003). Yabanct ülke mahkemelerinden alh nan velayet konusundaki ilamlann Türkiye'de tenfizi. [Enforcement of the Custody Judgments of Foreign Courts in Turkey], Atatürk Üniversitesi Erzincan Hukuk Fakültesi Dergisi, 722-56.

Şanll, C. (1996). Türk hukukunda çocuklann velayetine ve korunmastna ilişkin yabancl mahkeme kararlannin taninmast ve tenfizi. [Recognition and Enforcement of Foreign Child Custody and Child Protection Judgments under Turkish Law], Milletlerarası Özel Hukuk Bülteni, 16 (1-2), 71-82.

Schulman, J. and Pitt, V. (1982). 'Second thoughts on joint child custody: analysis of legislation and its implications for women and children', Golden Gate University Law Review 12 (3), 539-77.

Şener, E. (1994). Nafaka-Velayet-Vesayet-Evlathk-Babalk.[Alimony-Custody-Guardianship-AdoptionFatherhood], Ankara: Seçkin.

Singer, A. (2008). 'Active parenting or Solomon's justice? Alternating residence in Sweden for children with separated parents', Utrecht Law Review 4 (2), 35-48.

Steinman, S. B., Zemmelman, S. E. and Knoblauch, T. M. (1985). 'A study of parents who sought joint custody following divorce: who reaches agreement and sustains joint custody and who returns to court', Journal of American Academy of Child Psychiatry 24 (5), 554-62.

Tiryakioğlu, B. (1996). Yabanc Boşanma Kararlannın Türkiye'de Tanınması ve Tenfizi. [Recognition and Enforcement of Foreign Divorce Judgments in Turkey], Ankara: Ankara Üniversitesi Hukuk Fakültesi. 